\title{
Accounting
}

\section{Retracted: Education and gender wage gap: Evidence from Indonesia}

\author{
Suharyono $^{\mathrm{a}^{*}}$ and Kumba Digdowiseiso ${ }^{\mathrm{b}}$
}

aAssociate Professor, Department of Management, Faculty of Economics and Business, University of National, Jakarta, Indonesia

${ }^{b}$ Senior Lecture, Department of Management, Faculty of Economics and Business, University of National, Jakarta, Indonesia

\begin{tabular}{l}
\hline C H R O N I C L E \\
\hline Article history: \\
Received: July 2, 2020 \\
Received in revised format: \\
September 302020 \\
Accepted: October 15, 2020 \\
Available online: \\
October 15, 2020 \\
\hline Keywords: \\
Education \\
Gender \\
Wage \\
Globalization \\
Indonesia
\end{tabular}

\section{A B S T R A C T}

\begin{abstract}
This paper empirically tried to analyze the effects of education on the gender wage gap in Indonesia and to examine whether globalization could alter such a relationship. We modified a decomposition method for the panel dataset that corresponds to the National Socio-Economic Survey from 1996 to 2016. Overall, we found that schooling could significantly influence the salary discrepancy. We also proved that globalization did matter in explaining the relationship between the educational attainment and the salary gap. Here, it could widen the difference in the remuneration. Based on the results, strengthening the gender-responsive budget at the national government level might be one of the solutions. Basically, it actually started with a new awareness of the budget that was not genderneutral. Thus, the positioning of women in education and decision-making process is very crucial for the future of development.
\end{abstract}

\section{Introduction}

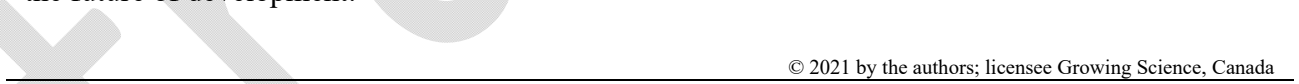

Theoretically, wage or remuneration is motivation of employees. Thus, gender wage parity not only protects human right, but also liberates labor force and optimizes economic resource distribution. Numerous countries in the world actually suffer the aftermath of gender wage gap, particularly the developing and transition ones. This gap stems from both the traditional menfirst stereotypes and the ideology which restrain women to access to education and thereby their remuneration (Digdowise, 2018). The current studies have given rich evidences on the positive relationship between education and gender wage equality. Furthermore, various economic reforms, such as domestic reform and globalization, will differently affect this gap and its determinants in general. Finally, low investment on women education and a lack of concern on gender-based education policies are still a major hindrance in the transition and developing countries, like Indonesia (Digdowise, 2018). As a typical developing and transition economy, Indonesia has witnessed a decade of policy reforms and transition towards democracy during the 2000s, following the rise on wage inequality between 1996 and 2009 and large wage disparities in terms of gender and industry (Matsumoto \& Verick, 2011). There are some factors that contribute to these gaps. But education is considered as the most important personal factor to halt the difference. In Indonesia, the gender wage inequality can further widen if more highly educated workers join the labor market (Matsumoto \& Verick, 2011). Additionally, the effect of globalization on the gender wage gap is clearly complex, positive or negative, with the contradictory ways of influence (Potrafke \& Ursprung, 2011). These

* Corresponding author

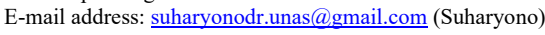


arguments raise interesting investigations whether education can close the difference in remuneration and how the impact of education changes without and with globalization. Therefore, the main contribution of this essay is to fill these gaps. In this context, our model is built based on the factors that affect gender wage gap using the extended model of decomposition method, developed by Oaxaca (1973) and Blinder (1973). The panel data is extracted through the National Socio-Economic Survey (Survei Sosial Ekonomi Nasional - SUSENAS) from 1996 to 2016.

The next section disentangles literature review on education and gender wage gap in Indonesia. We then present a new dataset and methodology that are closely related to the aspects of salary discrepancy. Before presenting the conclusions, we will obtain the econometric results based on several characteristics such as education, occupation, culture, geography, reform, and globalization.

\section{Literature Review}

There are several empirical examinations between education and gender wage gap. For example, Matsumoto and Verick (2011) put more attention on the trends and the determinants of employment status. They used National Labour Force Survey (Survei Ketenagakerjaan Nasional - SAKERNAS) data over the period 1996 - 2009. By using a multinomial logit model, the findings confirmed that men workers tend to be better educated than women. Also, the educational attainment did matter for ensuring workers to find a permanent employment. However, such effect seemed to be more limited for women than men. Looking at the earning differential conditions between male and female workers, Pirmana (2006) tried to disentangle the formal sectors in Indonesia, using data from SAKERNAS in 1996, 1999, 2002, and 2004. The results proved that the human capital factors, the socio-demography-economic characteristics, and location factors significantly affected individual earning in Indonesia. In addition, there was an evident of the inverted U-shape pattern between experience and earnings. In a more specific study at the micro level during the period 1994 - 2007, Sakellariou (2009) investigated the changing wage distributions and wage inequality across the distribution of earnings, as well as the relative contribution to these changes on earnings endowments, generating from various characteristics such as skills and the reward (price). The study showed that the contribution of changes in characteristics was driven by the increasing education attainment, while the effect of changes in 'prices' was dominated by the developments in the reward of more skilled occupations. In addition, the effect of skill was associated with the increase in the endowment of higher skills, especially for women. Another specific study conducted by Gunawan (2012) only attempted to reveal the effect of the additional years of schooling on the individual earnings and how education played a pivotal role in the final earnings of workers over the period 1989 - 2009. The finding confirmed that schooling significantly affected earnings. In addition, the estimated coefficient revealed that the effect of education on earnings was larger as education level increased. The result also proved that females earned more income than males in all levels of education.

Some studies link globalization on gender wage gap in Indonesia. The latest one comes from Fitrania (2013) in which he observed gender inequality in Indonesia in terms of gender wage gap and analyzed its relation on globalization from 2001 to 2010. The findings confirmed that all proxies of globalization were positively and significantly correlated with the occupational gender wage gap. In addition, it seemed to compensate for the unobservable human capital differences to some extent, while the residual wage gap only controlled for the observable human capital differentials. To sum up, unlike the previous literature reviews on the education - gender wage gap nexus, we attempt to investigate whether education variables, measured by education attainment and learning by doing, can have a significant impact on reducing the discrepancy in salary among gender. Factors that contribute to gender wage gap such as occupation, culture, and geography, are taken into account. In contrast to Fitrania's (2013) study, we also add variable of inflation, net export, and industrial sector to capture the nuance of reform and globalization comprehensively.

\section{Empirical Methodology}

We start with a simple unadjusted model of wage determination in such a way that:

$$
\ln w_{i t}=X_{i t} \beta_{i t}+\varepsilon_{i t},
$$

where $w_{i t}$ denotes the natural logarithm of weekly wages for an individual $i$ at year $t, X_{i t}$ presents a set of observed characteristics, $\beta_{i t}$ corresponds to the regression coefficients, and $\varepsilon_{i t}$ is a random error term. Then the human capital wage equation is estimated by Mincer (1974) in the following terms:

$$
\ln w_{i t}=X_{i t} \beta_{i t}+D_{i t} \gamma_{i t}+\varepsilon_{i t},
$$

where $\mathrm{D}_{\mathrm{it}}=1$ if women and otherwise is men, yit is the coefficient of the gender dummy variable. The men's and women's wage functions are measured separately such that: 
$\operatorname{Ln} w^{m}{ }_{i t}=X^{m}{ }_{i t} \beta^{f}{ }_{i t}+\varepsilon^{m}{ }_{i t}$,

$\operatorname{Ln} w_{i t}^{f}=X^{f} \beta_{i t}^{f}+\varepsilon_{i t}^{f}$,

where $m$ denotes men and $f$ is women. By subtracting the second equation from the first equation, a simple difference of log mean wage between men and women can be measured such that:

$$
\operatorname{Ln} w^{m}{ }_{t}-\operatorname{Ln} w_{t}^{f}=X^{m}{ }_{t} \beta_{t}{ }_{t} X^{f}{ }_{t} \beta_{t}^{f}+u_{t}
$$

Oaxaca (1973) and Blinder (1973) then developed decomposition approaches to separate the gender wage differential into components caused by two factors, namely:

If the reference group is men: $\operatorname{Ln} w^{m}{ }_{t}-\operatorname{Ln} w_{t}^{f}=\left(X^{m}{ }_{t}-X_{t}^{f}\right) \beta^{m_{t}}+\left(\beta^{m_{t}}-\beta^{f}\right) X^{f}+u_{t}$,

If women as the reference group: $\operatorname{Ln} w^{m}{ }_{t}-\operatorname{Ln} w_{t}^{f}=\left(X^{m}{ }_{t}-X_{t}{ }_{t}\right) \beta^{f}+\left(\beta^{m}{ }_{t}-\beta_{t}{ }_{t}\right) X^{m}{ }_{t}+u_{t}$

The difference of gender wage gap is decomposed into two terms in the right hand side of the above equation: i) gap due to differences characteristics, which could be observed between men and women, named 'observed X's' or 'observed gender gap in characteristics'; ii) unexplained wage gap caused by the differences of coefficients or returns to characteristics $X$, named 'gender discrimination'. However, the problem of this Blinder-Oaxaca decomposition is that decomposition is unstable depending on the choice of the group (men or women). Then, Neumark (1988) generalized the decomposition such that:

$$
\operatorname{Ln} w^{m}{ }_{t}-\operatorname{Ln} w_{t}^{f}=\left(X^{m}{ }_{t}-X_{t}^{f}\right) \beta_{t}+\left(\beta^{m}{ }_{t}-\beta_{t}\right) X^{m}{ }_{t}+\left(\beta^{f}{ }_{t}-\beta_{t}\right) X_{t}^{f}+u_{t}
$$

where $\beta_{t}$ is the non-discriminatory wage structure. Following Eq. (6), the decompose model is divided into three terms, including: i) the gender wage gap caused by differences in characteristics; ii) the gap due to difference of factual and the pool returns for male; and iii) the gap due to the difference of factual and the pool returns for female. In order to further extended to the decomposition of change over time, from year $t$ - $j$ to year $t$, the Blinder - Oaxaca's decomposition could be developed such that:

$$
g\left(\operatorname{Ln} w_{t}\right)-g\left(\operatorname{Ln} w_{t-j}\right)=\left(\operatorname{Ln} w_{t}^{m}-\operatorname{Ln} w_{t}^{f}\right)-\left(\operatorname{Ln} w_{t-j}^{m}-\operatorname{Ln} w_{t-j}^{f}\right)=\left(d X^{m}-d X^{f}\right) \beta^{m}{ }_{t}+\left(d \beta^{m}-d \beta^{f}\right) X_{t-j}^{f}+g X_{t-j} \times d \beta^{m}{ }_{t-j}+d X^{f} \times g \beta_{t}+d u \text {. }
$$

In the Eq. (7) the decomposition of gender wage gap concludes 4 (four) terms in the right-hand side, as follows: i). The first term denotes the change in wage gap caused $y$ changes in the characteristics between men and women; ii). The second term represents the difference in the wage gap results from changes in the coefficient or discrimination; iii). The third term constitutes the interaction effect which represents changes over time of the coefficients weighted by the gender gap in time $t-j$. When male is used as the reference group, the positive term indicates an increase in the coefficient where males have an advantage; and iv). The last term is an interaction term that constitutes the changes in characteristics over time weighted by the gender gap in the coefficient in time $t$. A positive value of the last term indicates growth in characteristics over time where they were disadvantaged in terms of the payoff. To present the determinants of wage that take into account reform and globalization over the period 1996 - 2016, Eq. (1) is more specified as in Eq. (8) such that:

$$
\ln w_{i t}=X_{i t} \beta_{i t}+\gamma Z^{*} E_{i t}+\varepsilon_{i t},
$$

where $Z$ is globalization and reform variables, $\mathrm{E}$ is education variables that constitute education and learning by doing, and $X$ is control variables that include occupation, as well as several cultural and geographical factors (see Pirmana, 2006; Matsumoto \& Verick, 2011; Sakellariou, 2009; Fitrania, 2013). All data on independent variables are obtained from SUSENAS through our statistical agency (Badan Pusat Statistik - BPS). While data on dependent variable are also collected through BPS on SAKERNAS over the period $1996-2016$.

\section{Empirical Results and Discussions}

Generally, education is a significant determinant of gender wage (see Table 1). The higher levels of education generally contribute to the higher return. The female with college degree and above will receive a higher wage than those without that degree from about $156 \%$ in 1996 to $132 \%$ in 2016. In addition, female gains a relatively higher return to education than male at the same education level. This finding was similar with Behrman and Deolalikar's (1991) result in which they found that the higher levels of education, the higher the rate of return on the individual. However, the comparison between male and female earning differentials was neglected in their study. 
Table 1

The effect of education on gender wage over the period 1996-2016

\begin{tabular}{|c|c|c|c|c|c|c|c|c|c|c|c|c|}
\hline & \multicolumn{2}{|c|}{1996} & \multicolumn{2}{|c|}{2000} & \multicolumn{2}{|c|}{2004} & \multicolumn{2}{|l|}{2008} & \multicolumn{2}{|c|}{2012} & \multicolumn{2}{|c|}{2016} \\
\hline & Male & Female & Male & Female & Male & Female & Male & Female & Male & Female & Male & Female \\
\hline Education & $(1)$ & (2) & (3) & (4) & $(5)$ & $(6)$ & $(7)$ & $(8)$ & (9) & $(10)$ & $(11)$ & $(12)$ \\
\hline Primary School & $\begin{array}{c}0.2149 * * * \\
(0.011)\end{array}$ & $\begin{array}{c}0.2651 * * * \\
(0.015)\end{array}$ & $\begin{array}{c}-0.2087 * * * \\
(0.015)\end{array}$ & $\begin{array}{c}-0.1540^{* * * *} \\
(0.022)\end{array}$ & $\begin{array}{c}-0.5515 * * * \\
(0.018)\end{array}$ & $\begin{array}{c}-0.5251 * * * \\
(0.029)\end{array}$ & $\begin{array}{c}-0.6866^{* * * *} \\
(0.016)\end{array}$ & $\begin{array}{c}-0.8487 * * * \\
(0.025)\end{array}$ & $\begin{array}{c}0.2116^{* * *} \\
(0.011)\end{array}$ & $\begin{array}{c}0.3371^{* * * *} \\
(0.022)\end{array}$ & $\begin{array}{c}0.0631^{* * *} \\
(0.021)\end{array}$ & $\begin{array}{c}0.1431 * * * \\
(0.029)\end{array}$ \\
\hline $\begin{array}{l}\text { Secondary } \\
\text { School }\end{array}$ & $\begin{array}{c}0.4306^{* * * *} \\
(0.013)\end{array}$ & $\begin{array}{c}0.6682 * * * \\
(0.021)\end{array}$ & $\begin{array}{c}-0.0644 * * * \\
(0.017)\end{array}$ & $\begin{array}{c}0.1484 * * * \\
(0.029)\end{array}$ & $\begin{array}{c}-0.3868^{* * *} * \\
(0.018)\end{array}$ & $\begin{array}{c}-0.2265 * * * \\
(0.030)\end{array}$ & $\begin{array}{c}-0.5572 * * * \\
(0.016)\end{array}$ & $\begin{array}{c}-0.5218^{* * * *} \\
(0.026)\end{array}$ & $\begin{array}{c}0.2820^{* * * *} \\
(0.035)\end{array}$ & $\begin{array}{c}0.4148 * * * \\
(0.080)\end{array}$ & $\begin{array}{c}0.2045^{* * * *} \\
(0.021)\end{array}$ & $\begin{array}{c}0.3278^{* * * *} \\
(0.029)\end{array}$ \\
\hline High School & $\begin{array}{c}0.7068^{* * * *} \\
(0.011)\end{array}$ & $\begin{array}{c}1.1721^{* * * *} \\
(0.015)\end{array}$ & $\begin{array}{c}0.2526 * * * \\
(0.014)\end{array}$ & $\begin{array}{c}0.7472 * * * \\
(0.020)\end{array}$ & $\begin{array}{c}-0.0636^{* * * *} \\
(0.017)\end{array}$ & $\begin{array}{c}0.2326^{* * * *} \\
(0.028)\end{array}$ & $\begin{array}{c}-0.2252^{* * * *} \\
(0.015)\end{array}$ & $\begin{array}{c}-0.0744^{* * * *} \\
(0.024)\end{array}$ & $\begin{array}{c}0.3658^{* * *} \\
(0.022)\end{array}$ & $\begin{array}{c}0.4649 * * * \\
(0.043)\end{array}$ & $\begin{array}{c}0.5735^{* * * *} \\
(0.022)\end{array}$ & $\begin{array}{c}0.9030^{* * *} \\
(0.029)\end{array}$ \\
\hline $\begin{array}{l}\text { Vocational } \\
\text { school }\end{array}$ & $\begin{array}{c}0.1026^{* * *} \\
(0.025)\end{array}$ & $\begin{array}{c}0.1722 * * * \\
(0.055)\end{array}$ & $0.0957 * * *$ & 0.1186 & $\begin{array}{c}0.1029 * * * \\
(0.032)\end{array}$ & $\begin{array}{l}0.0897 \\
(0.063)\end{array}$ & $\begin{array}{c}0.1193 * * * \\
(0.029)\end{array}$ & 0.0073 & $0.1389 * * *$ & $0.1478^{*}$ & $0.3194 * * *$ & $0.4402 * * *$ \\
\hline College or higher & $\begin{array}{c}1.1626^{* * * *} \\
(0.015)\end{array}$ & $\begin{array}{c}1.5549 * * * \\
(0.022)\end{array}$ & $\begin{array}{c}0.6488^{* * * *} \\
(0.026)\end{array}$ & $\begin{array}{c}1.0791 * * * \\
(0.031)\end{array}$ & $\begin{array}{c}0.3026^{* * *} \\
(0.022)\end{array}$ & $\begin{array}{c}0.6238^{* * * *} \\
(0.031)\end{array}$ & $\begin{array}{c}0.1691 * * * \\
(0.020)\end{array}$ & $\begin{array}{c}0.3274^{* * * *} \\
(0.028)\end{array}$ & $\begin{array}{c}0.9184^{* * * *} \\
(0.055)\end{array}$ & $\begin{array}{c}1.1469^{* * * *} \\
(0.090)\end{array}$ & $\begin{array}{c}1.0903 * * * \\
(0.024)\end{array}$ & $\begin{array}{c}1.3185^{* * *} \\
(0.029)\end{array}$ \\
\hline Constant & $\begin{array}{c}9.7267 * * * \\
(0.009)\end{array}$ & $\begin{array}{c}8.9990 * * * \\
(0.011)\end{array}$ & $\begin{array}{c}12.3454^{* * * *} \\
(0.012)\end{array}$ & $\begin{array}{c}11.6236 * * * \\
(0.016)\end{array}$ & $\begin{array}{c}13.9838 * * * \\
(0.015)\end{array}$ & $\begin{array}{c}13.4263 * * * \\
(0.026)\end{array}$ & $\begin{array}{c}14.1615 * * * \\
(0.014)\end{array}$ & $\begin{array}{c}13.7577 * * * \\
(0.022)\end{array}$ & $\begin{array}{c}8.5444^{* * * *} \\
(0.006)\end{array}$ & $\begin{array}{c}8.0553^{* * * *} \\
(0.010)\end{array}$ & $\begin{array}{c}8.5683 * * * \\
(0.018)\end{array}$ & $\begin{array}{c}8.0520 * * * \\
(0.024) \\
\end{array}$ \\
\hline Observations & 30995 & 13832 & 19182 & 9117 & 22903 & 10381 & 26227 & 12070 & 23835 & 9572 & 20970 & 10377 \\
\hline$R^{2}$ & 0.227 & 0.417 & 0.099 & 0.262 & 0.132 & 0.195 & 0.153 & 0.232 & 0.060 & 0.071 & 0.186 & 0.281 \\
\hline
\end{tabular}

As we see in Table 2, the impact of education on wage changes significantly. The strongest impact of education on gender wage is also expressed at the highest level of education. Even, under the context of other factors, the dominant role of education on wage, especially for women, remains stable. Here, female still has higher education return than male, particularly at the high school level above. In addition, primary school has more positive effects on gender wage than vocational school. Thus, it seems that the vocational education in Indonesia is not really effective to tackle the difference in remuneration. In general, we find that the higher the education, the higher the growth of the wage. Elfindri (2001) explained that education would bring the consequences and the choices to individuals in finding jobs in a bid to obtain the higher incomes. If compared to the workers with the secondary and higher education, the low rate of return from primary and junior high school graduates is caused by the low quality of education that they received in the past. However, at the present time, many students receive the opposite one. Another factor is apparently due to the current job market requirement at both government and private sectors. In this context, they only receive the candidates with a minimum of diploma background for conducting various types of work. But in reality, these positions often do not match with the criteria. For example, instead of using a candidate from the senior high school background, the job position of messenger and office boy in Indonesia nowadays requires the candidates who have diploma background. Pertaining to the learning by doing, experience gives a positive effect on wage for all gender. But, generally, such effect is more favorable for female. Meanwhile, age and experience may affect gender wage for various reasons (van Ours \& Stoeldraijer, 2010). For example, the older workers are thought to be more reliable and to have better skills than average workers. However, they may impose a higher cost in terms of the health-care, may have a lower flexibility in accepting new assignments and may have less suitable for training. In our case, we find that age and experience have a positive effect on wage. Here, the older workers tend to have higher salary than their juniors. In addition, they are usually placed at the top position level. But, overall, the difference between the older male and female in terms of earnings still exists. In this context, we analyze that the older the woman, the more she has a concern to her family. This is because woman in Indonesia has a different life-cycle and role compared to man (Sugiyanto \& Digdowiseiso, 2019). In terms of non-linearities, the effect of age does not simultaneously increase with wage. Instead, such relationship is in the convex form, as explained by the negative and significant coefficient on the squared age. At occupation factors, it can be understood that the professional will be a new destination on any occupation for the future development in Indonesia. Moreover, industrialization in Indonesia, which is measured by the number of workers at the industrial sector, seems to give a larger contribution on both female and male workers' wage, except from 2012. The worst performance on the Indonesia economy takes place after 2008 since there was a spillover effect of sub-prime mortgage crises that influenced both financial and real sector. This suggests that in terms of wage, the female workers are more vulnerable than male under the economic shocks. Based on such condition, women are very sensitive to the 'typical' environment, where they receive more returns from reform as well as globalization, but they also suffer from the economic shock or crisis. For other factors of reform and globalization, the net export contributes to earning differential during the period 1996 - 2016, giving more effects to the male. While the effect of inflation depends more directly on the economic contexts, such as negative in the event of shock or crisis in 2004 and 2008, and positive in the recovery period from 2012 onwards.

In terms of cultural and geographical factors, working area has positive effects on wage. Also, female workers have a higher wage in urban areas than women in rural areas. However, if compared to male worker, the female coefficient is quite low. According to Todaro and Smith (2015), various studies that were specifically conducted to analyze the process of migration from different countries have documented the existence of a positive relationship between the level of educational attainment with the tendency of people to migrate from their home villages. Basically, someone who is highly educated will face a higher wage differential since he or she has a greater opportunity to get a job in the modern sector. 
Marital status could also be barrier for female workers to increase their wage. In Indonesia, marriage allowances received by female are usually come from the male. In addition, though the amount of wage is positive for both gender, but female workers only increase less than a half, compared to male workers. Such condition shows that although we gradually enjoy the equality, the gap between gender still exists due to marital status. Thus, the need to increase education on woman is very crucial, which not only stimulates the productivity in farms and in factories, but also it lifts woman's participation in the labor force. This, in turn, contributes to the later marriage, lowers fertility, as well as improves the health and nutrition of children. Beside marital status, the size of household also affects the income. We find that if the worker has only 4 (four) family members or less, the total wage will increase gradually. Also, the increase in wage for female worker is even higher than male worker. Therefore, households with a small number of family members have a greater trade-off than those with a high one.

Table 2

OLS regressions on gender wage over the period 1996-2016

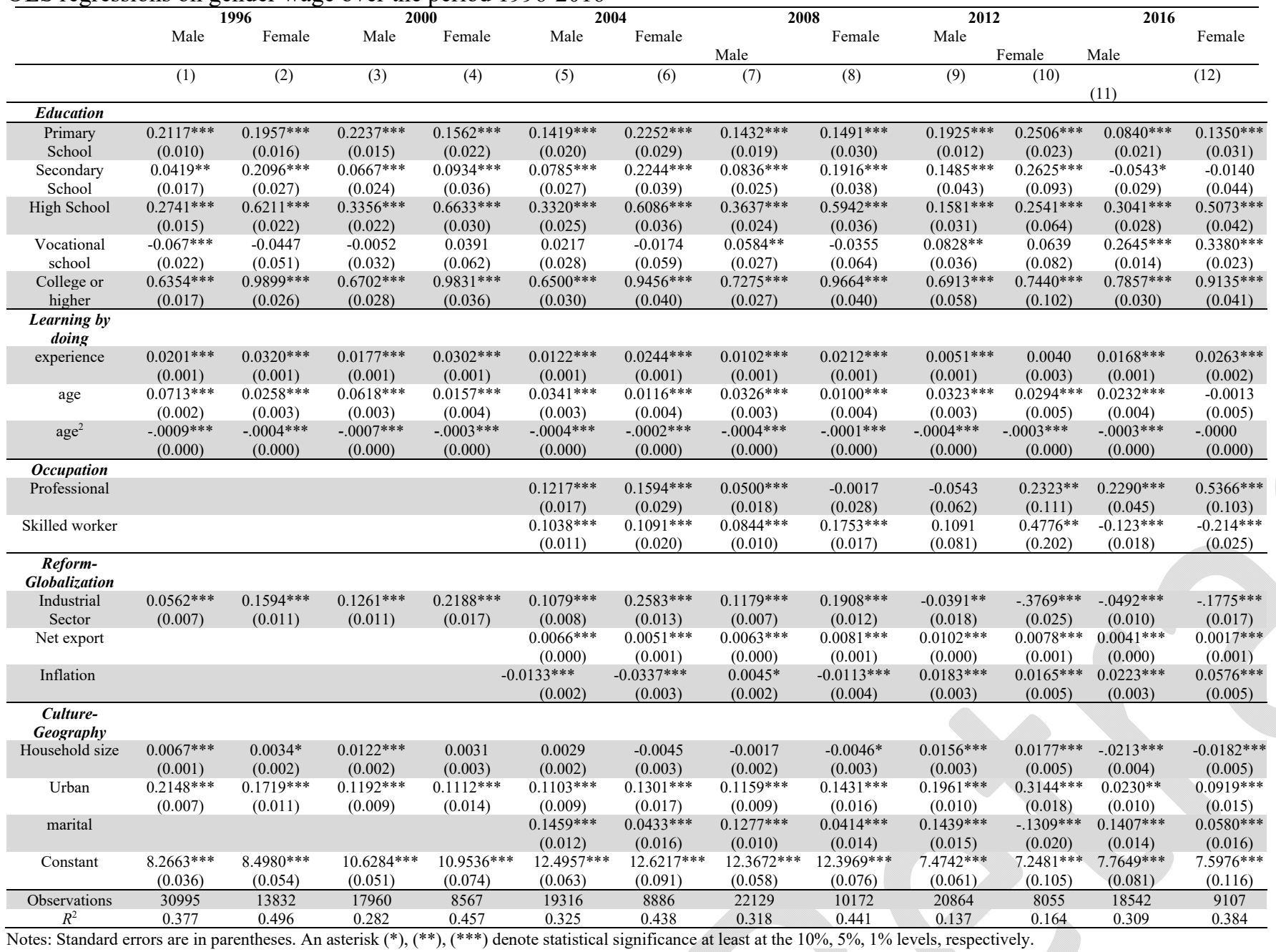

In Table 3, we decompose the individual differentials of factors on gender wage gap. The below results are expressed by the following comparisons: 1996 versus 2000, 2004 versus 2008, 2012 versus 2016, respectively. In addition, the factors related to learning by doing, occupation, reform and globalization, culture and geography are taken into account. Besides, such specifications also support for the comparison of education effects with others. In general, the gender wage inequality in Indonesia has been fluctuated. It significantly decreased at nearly $8.3 \%$ over the period $1996-2000$, where the Indonesia economy have significant difficulties, as well as strong reforms. Then, it is followed by a small percentage of reduction at $1.43 \%$ during $2004-2008$ and around $16 \%$ during 2012 - 2016. In particular, the fluctuation of unobserved/residual gap, which includes the gender discrimination, tends to determine the trend of the gap, when $\mathrm{D}$ and $\mathrm{U}$ have the same sign in all periods. This implies the important role of gender discrimination on the wage discrepancy in Indonesia. In terms of education effect, we find that education plays an important role in reducing the gender wage inequality in the past two decades. In the group of education attainment, the strongest effect belongs to the college or higher education level. It is important to note that the impact of education increases significantly at the end of this decade where the price of female's comparative education factor is higher. That is, when the coefficient of Pe remains negative, from -0.0026 during $2004-2008$ to -0.0140 during $2012-2016$. 
In comparison with other factors that reduce gender wage gap, learning by doing places the pole position. Such factor has a higher impact on narrowing the inequality on gender wage during $1996-2000$, where the gap lowers by $3.8 \%$. However, the sign of this effect has not consistent over time. In the event of the economic crisis on the year 2008, the coefficients of occupation, reform and globalization turn to increase the gender wage gap. Also, the factors of reform and globalization in Indonesia seem to produce the inequality where both have increased the gender wage gap by $0.21 \%$ during $2004-2008$ and $0.85 \%$ during $2012-2016$. Those factors that contribute negatively to the gender wage discrimination include industrialization and inflation, which are usually characterized as the unsustainability in the economic growth.

Table 3

Summary of decomposition

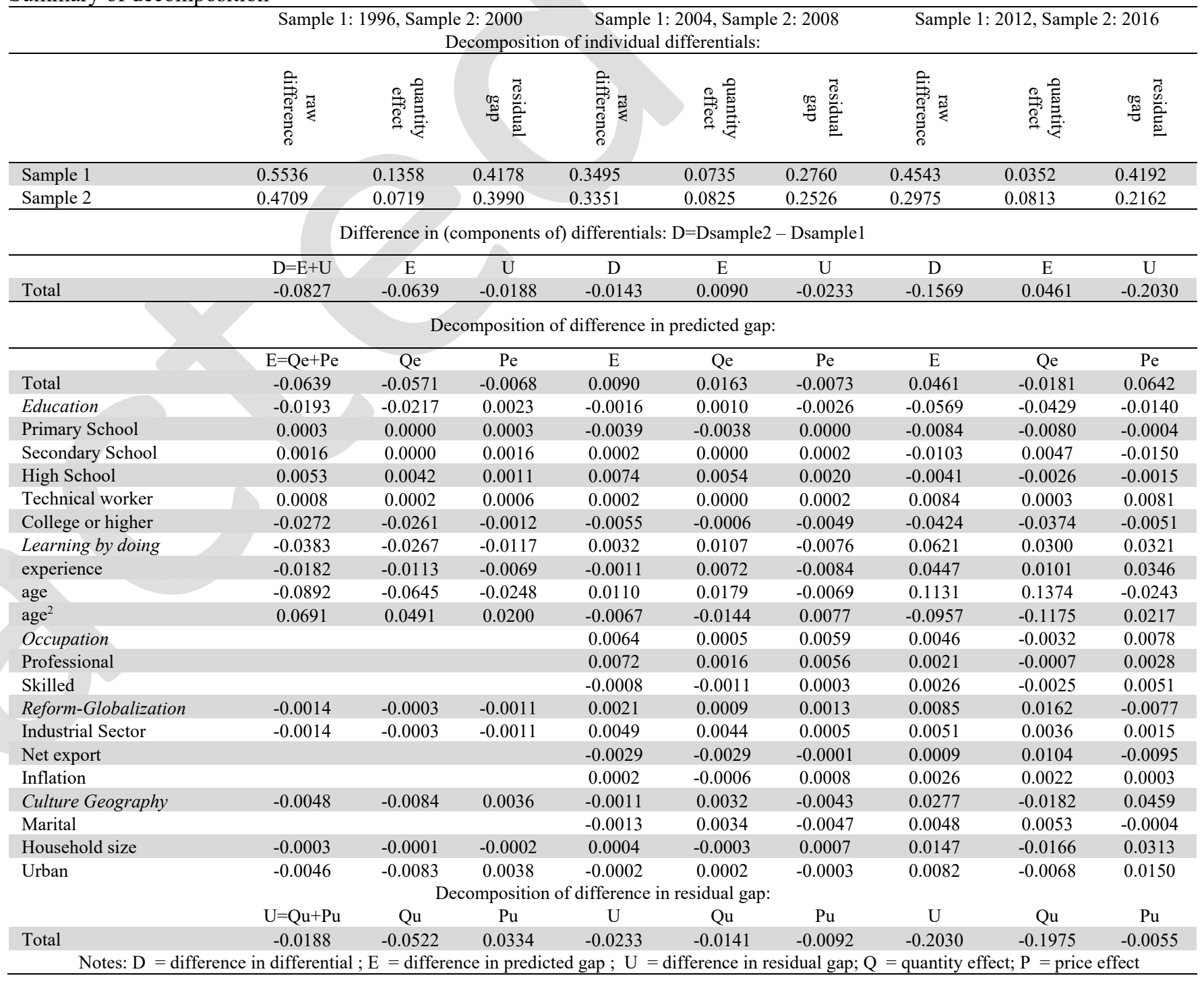

\section{Conclusion}

In this study, we have tried to investigate whether education can affect gender wage gap. In addition, we also examine whether globalization can change the relationship between education and earning differential among gender. Overall, we have found that education can significantly influence gender wage gap where the strongest impact of education on gender wage can be found at college level and above. We also prove that globalization does matter in explaining the relationship between salary gap and education. Here, globalization itself can widen the wage discrepancy among gender. However, the magnitude of education on this gap improves significantly after globalization. 
Future studies can assess the phenomenon of the gender salary gap with different industries and provinces background. In this context, we are not able to conduct the Blinder - Oaxaca decomposition due to the small number of observations. In addition, this study does not incorporate different types of foreign direct investment (FDI) and trades at sub-national level on the estimation of the gender earning differential due to the unavailability of the data at the time of our research. Thus, such limitation may provide another dimension for future research in Indonesia.

There are some development policy considerations that can be drawn from this study in a bid to decrease the differential in earning among gender. Strengthening gender responsive budget at the national government level can be one of solutions. Basically, it actually started with a new awareness of the budget that was not gender neutral. In fact, any program / budget always gives a different effect between men and women. In some cases, although a lot of the budget has been assessed with some proportion of the allocation went to pro-poor public spending and fulfilled the basic rights of the people, but in practice, it gave a different implication between men and women in the socio-economic relations as majority of women tended to be left behind. Thus, positioning of women in education and decision-making process is very crucial for the future of development.

\section{Acknowledgements}

This research received no specific grants from any funding agency in the public, commercial, or not-for-profit sectors. The authors would like to convey a big gratitude to our colleagues at Department of Management and Department of Public Administration at University of National for the input. We were also grateful to Prof. Cristopher Findlay from Adelaide University and Ass. Prof. Pataporn Sukontamarn from Chulalongkorn University for their critical evaluation on the research method. Additionally, we wish to thank the referees and editors for their suggestions.

\section{References}

Behrman, J.R., \& Deolalikar, A. (1991). School Repetition, Dropouts, and The Rates of Return to schooling: The Case of Indonesia. Oxford Bulletin of Economics and Statistics, 53(4), 467-480. Doi: https://doi.org/10.1111/j.14680084.1991.mp53004007.x

Blinder, A.S. (1973). Wage Discrimination Reduced Form and Structural Estimates. Journal of Human Resources, 8(4), 436455. Doi: $10.2307 / 144855$

Digdowise, K. (2018). Reexamining the economic growth - education inequality - income distribution nexus in Indonesia. Journal of Applied Economic Sciences, 13(4), 987-996.

Elfindri. (2001). Ekonomi SDM. Padang: Andalas University Press.

Fitrania, S.N. (2013). The Impact of Globalization on Gender Wage Gap in Indonesia: A Sub-National Level Analysis. Master Thesis, Tilburg: Tilburg University.

Gunawan, E. (2012). The wage effects on education: An analysis by gender in Indonesia. International Journal of Social Sciences and Humanities Studies, 4(1), 117-126.

Matsumoto, M., \& Verick, S. (2011). Employment Trends in Indonesia over 1996 - 2009: Casualization of The labour Market during an Era of Crises, Reforms, and Recovery. Retrieved October 10, 2019,

Mincer, J. (1974). Schooling, Experience, and Earnings. New York: Columbia University Press.

Neumark, D. (1988). Employers' discriminatory behaviour and the estimation of wage discrimination. Journal of Human Resources, 23(3), 279-295. Doi: 10.2307/145830

Oaxaca, R.L. (1973). Male-Female Wage Differentials in Urban Labor Markets. International Economic Review, 14(3), 693709. Doi: $10.2307 / 2525981$

Pirmana, V. (2006). Earning Differentials Between Male-Female In Indonesia: Evidence from SAKERNAS Data. Retrieved October 12, 2019, from http://ceds.feb.unpad.ac.id/wopeds/200608.pdf

Potrafke, N., \& Ursprung, H.W. (2011). Globalization and Gender Equality in Developing Countries. Retrieved October 11, 2019, from https://core.ac.uk/download/pdf/6436974.pdf

Sakellariou, C. (2009). Changing Wage Distributions and the Evolution of Wage Inequality in Indonesia: 1994 - 2007. Retrieved October 11, 2019, from

Sugiyanto, E., \& Digdowiseiso, K. (2019). Do incidence and duration of child labour matter on schooling in Indonesia?. International Journal of Education Economics and Development, 10(1), 22-35.

Todaro, M.P., \& Smith, S.C. (2015). Economic Development. New York: Pearson.

van Ours, J.C., \& Stoeldraijer, L. (2010). Age, Wage, and Productivity. Discussion Paper, No. 4765, Bonn: The Institute for Study of Labor (IZA). Retrieved 
